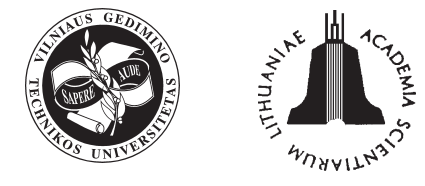

ISSN 1392-8619 print/ISSN 1822-3613 online

\title{
ON THE ADAPTABILITY OF CONCRETE-FILLED STEEL TUBULAR COLUMNS IN THE LIGHT OF THE POST-FIRE TESTING RESULTS
}

\author{
Žygimantas Blaževičius \\ Dept of Steel and Timber Structures, Vilnius Gediminas Technical University, \\ Sauletekio al. 11, LT-10223 Vilnius, Lithuania \\ E-mail:zygiui@centras.lt
}

Received 24 October 2006; accepted 7 June 2007

\begin{abstract}
The objective of this work is assessment of the applicability of the concrete-filled steel tubular columns for their further maintenance after exposing to fire. The properties of steel and concrete after heating are briefly described, as well as the attributes of the structures indicating temperature reached during the fire. An experimental research on the HC-FST (hollow concrete-filled steel tubular) column behaviour under post-fire conditions was performed. Behaviour of 16 axially loaded HC-FST columns has been experimentally investigated and the results presented in this paper. The experimental values of the post-fire resistance were measured and failure mode was determined for 4 axially loaded columns. For the comparison of test parameters, 4 axially loaded HC-FST columns were tested under normal conditions. In addition, 8 hollow concrete-filled steel tubular stub columns and 4 hollow concrete tubular stub columns under normal conditions were tested. One of the research objectives was preparing the experimental data for analysis and developing some analytical dependences between different test parameters influencing most significantly the post-fire resistance of HC-FST columns.
\end{abstract}

Keywords: mechanical properties, experimental investigation, concrete-filled steel tubular columns, post-fire resistance, load bearing capacity, axial loading.

\section{Introduction}

Composite structures are wide spreading globally due to their mechanical and workability properties, which are well competitive with the properties of common homogeneous structures. Usually the components for composite building structures are selected to receive better their fire resistance.

Filling hollow steel columns with concrete has several benefits. One of the main benefits is a substantial increase in load-bearing capacity of column. In addition, a higher fire and post-fire resistance can be obtained compared with bare steel tubular and reinforced concrete columns. A great effect is tangible if even there is a hollow concrete core inside of steel section. Concrete-filled hollow steel section (HSS) columns have much better endurance characteristic than conventional reinforced concrete columns under fire as the steel casting prevents spalling of the concrete which remains better protected against fire. Another benefit is that the tubular form of the steel eliminates the need for formwork. The C-FST structures application gives a tangible economical effect [1].

A lot of normative documents are developed to regulate the design of building structures keeping well their work- ability under normal and fire conditions. The fire resistance of composite structures is under research quite often too, but it is quite seldom cases when the post-fire resistance of load bearing structures is under research. The normative documents regulating the estimation of applicability of composite structures after fire seem are not still prepared. From the purely practical point of view there is no need to consider the fire resistance of the building structures if they are already destroyed by the fire. Topical question is the safety of the further maintenance of the building when the main load-bearing structures of it have been exposed to fire.

For a post-fire resistance estimation such procedures may be suggested: 1) establishing the real temperature regime of fire under the particular case; 2) calculating the temperature distribution in the cross-section of the column during the fire; 3 ) calculating the axial buckling load of the column previously affected by elevated temperatures.

In many cases it is difficult a task to evaluate the temperature regime of the fire when it had been finished. One of the ways to determine fire parameters is measuring the structure cooling period [2]. If there were no intended observations or measurements of the fire parameters (time, 
temperature, amount of burning agent) evaluating according to the external markings on the structures previously exposed to fire is one of the ways for evaluating the temperature regime.

The temperature distribution for the elements with HCFST cross-section could be found using the FEM programmes. The buckling capacity of a column previously affected by fire should be calculated by estimating different deformation and strength indices of the materials (steel and concrete). There is a lot of information about the thermal and physical properties of steel and concrete at elevated temperatures, for instance [3-6], but there are not too much data about their properties after exposing to fire [6]. Therefore, the need for a deeper investigation of behaviour of the HC-FST columns after their exposing to fire exists.

The main objective of the research presented in this paper is the assessment of concrete-filled steel tubular columns applicability to their further maintenance after their exposing to fire conditions.

\section{Establishing the fire temperature regime and utilisation level of the steel and concrete mechanical properties}

In many cases the fire temperature regime subjected to the HC-FST columns can be reflected in the external markings on the concrete. The visible indications reflecting the maximum temperature were reached in the concrete during the fire are given in (Table 1) and agree with the data in [6]. These indications could be seen by removing the steel shell in the local area of the column. The maximum temperature of the steel shell approximately could be taken approximately the same as the maximum temperature reached on the outer surface of the concrete core.

One of the steps in the post-fire resistance estimation is the calculation of the temperature field inside of the building structure. The tabulated data or simplified methods are created for many types of cross-sections of homogeneous structures. In case of a composite structure the temperature distribution in the cross-section can be obtained due to the finite element modelling [7]. The result of such a calculation of HC-FST columns (with the geometrical properties of cross-section the same as those properties of tested specimens) is given in Fig 1. The temperature distribution in the cross-section after $45 \mathrm{~min}$ of the fire was calculated considering the temperature according to the standard fire temperature curve having the analytical expression [8]:

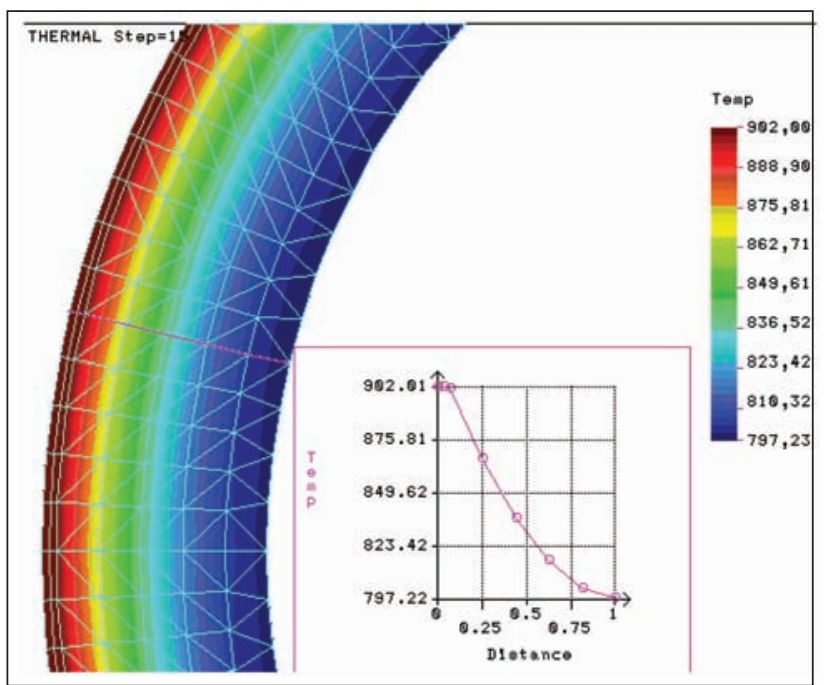

Fig 1. Temperature distribution in the cross-section of the HCFST column after $45 \mathrm{~min}$ of the standard fire

$$
t=345 \log _{10} \times(8 T+1)+20,
$$

where: $t$ - temperature ${ }^{\circ} \mathrm{C}, T$ - time from the fire beginning [min].

The influence of any moisture content and any moisture migration within the concrete was neglected as it is given in [9] for advanced calculation models.

In many cases the steel in the post-fire situation has the mechanical properties very similar to those before the fire. While the strength of steel is low in the fire situation, the mechanical properties of the concrete are not so extremely sensitive to high temperature in fire situation as the mechanical properties of the steel are. The concrete strength is very different in the post-fire situation depending on the reached maximum temperature.

The strength utilisation levels of steel and concrete are subjected to the maximum temperatures reached in the materials during the fire are given in Table 2 and agree to the data in [6]. When the utilisation level for mechanical properties of steel and concrete in the post-fire situation is not very low, it is suggested to perform the post-fire resistance calculation of HC-FST columns by the methods developed for calculating under normal ambient conditions. It is risky to suggest using the same methods when utilisation level of concrete is lower than $0,4-0,3$. Absolutely different material properties could be obtained and different

Table 1. The indications reflecting the maximum temperature reached during the fire

\begin{tabular}{|c|c|c|}
\hline Colour of the structure's concrete & $\begin{array}{l}\text { Maximum temperature reached in } \\
\text { the concrete }{ }^{\circ} \mathrm{C}\end{array}$ & Another defects may be observed \\
\hline Pink to red & $300-600$ & $\begin{array}{l}\text { Surface cracking (could be observed from } 300{ }^{\circ} \mathrm{C} \text { ) } \\
\text { Deep cracking (from } 500{ }^{\circ} \mathrm{C} \text { ) } \\
\text { Splitting the silica aggregate (from } 573{ }^{\circ} \mathrm{C} \text { ) }\end{array}$ \\
\hline Slate-coloured to rifle-green & $600-950$ & $\begin{array}{l}\text { Spalling of the concrete }\left(700-800{ }^{\circ} \mathrm{C}\right. \\
\text { Dissociated limed aggregates and crumbling } \\
\text { dehydrogenated cement stones }\left(900^{\circ} \mathrm{C}\right)\end{array}$ \\
\hline
\end{tabular}


Table 2. The utilisation level of the steel and concrete strength

\begin{tabular}{|l|c|c|c|c|c|c|c|}
\hline \multirow{2}{*}{ Material type } & \multicolumn{6}{c|}{ The utilisation level of the material strength subjectto the maximum temperature was reached } \\
\cline { 2 - 8 } & 60 & 120 & 150 & 200 & 300 & 400 & 500 \\
\hline $\begin{array}{l}\text { Heavy concrete under normal } \\
\text { consolidation conditions }\end{array}$ & 0,7 & 0,7 & 0,7 & 0,7 & 0,6 & 0,4 & 0,3 \\
\hline $\begin{array}{l}\text { Light concrete under } \\
\text { stepped-up consolidation } \\
\text { conditions }\end{array}$ & 0,9 & 0,9 & 0,9 & 0,9 & 0,9 & 0,85 & 0,8 \\
\hline Steel $\left(\mathrm{f}_{\mathrm{yd}}=225 \div 510 \mathrm{MPa}\right)$ & 1 & 1 & 1 & 1 & 1 & 1 & 1 \\
\hline Steel $\left(\mathrm{f}_{\mathrm{yd}}=510 \div 815 \mathrm{MPa}\right)$ & 1 & 1 & 1 & 1 & 1 & 0,95 & 0,9 \\
\hline Steel $\left(\mathrm{f}_{\mathrm{yd}}=815 \div 915 \mathrm{MPa}\right)$ & 1 & 1 & 1 & 1 & 1 & 0,9 & 0,8 \\
\hline Steel $\left(\mathrm{f}_{\mathrm{yd}}=915 \div 1250 \mathrm{MPa}\right)$ & 1 & 1 & 1 & 1 & 1 & 0,7 & 0,4 \\
\hline
\end{tabular}

behaviour of the composite structure could be observed in such cases.

\section{The experimental programme}

In order to receive an experimental data, the experimental research on the post-fire resistance of axially loaded HCFST columns was performed. Due to complexity of tests with HC-FST and HC columns under fire, their studies (involving natural size building structures) are carried out quite seldom in Lithuania and in neighbouring countries. The data of similar tests which are presented in this paper are described [10]. Pursuant to the study programme $20 \mathrm{HC}-\mathrm{FST}$ (Fig 2) and HC (hollow concrete) specimens have been tested under natural conditions and after exposing them to fire temperatures. The specimens were manufactured by cutting long columns. Such columns consisted of the spirally welded steel tubes, inside which hollow concrete cores were formed by centrifuging the mix. The outer diameter of the steel tube was $d_{e}=219 \mathrm{~mm}$, and the wall thickness was about $t_{a}=1,6 \mathrm{~mm}$. The wall thickness of the centrifuged concrete core of the HC-FST and HC columns varied $t_{c}=17-46 \mathrm{~mm}$.

12 short $(h=300 \mathrm{~mm})$ and 8 long $(h=2000 \mathrm{~mm}) \mathrm{HC}$ FST elements were fabricated by cutting them from the elements of initial 5,5 m length. The detailed information on specimens preparation and the test procedures is given in [11].

\section{Testing procedures}

According to experimental programme 4 short $\mathrm{HC}, 8$ short HC-FST and 4 long HC-FST specimens were prepared for testing under normal conditions and 4 long HCFST specimens were prepared for testing under post-fire conditions (after preheating). For determining the steel mechanical properties, the standard steel specimens were tested (in pursuance with the requirements [12]) through the wrapping test, and the compressive strength of concrete was determined by the tests of 4 short HC specimens. All specimens were prepared, and the tests carried out in the laboratories of the Faculty of Civil Engineering of Vilnius Gediminas Technical University.

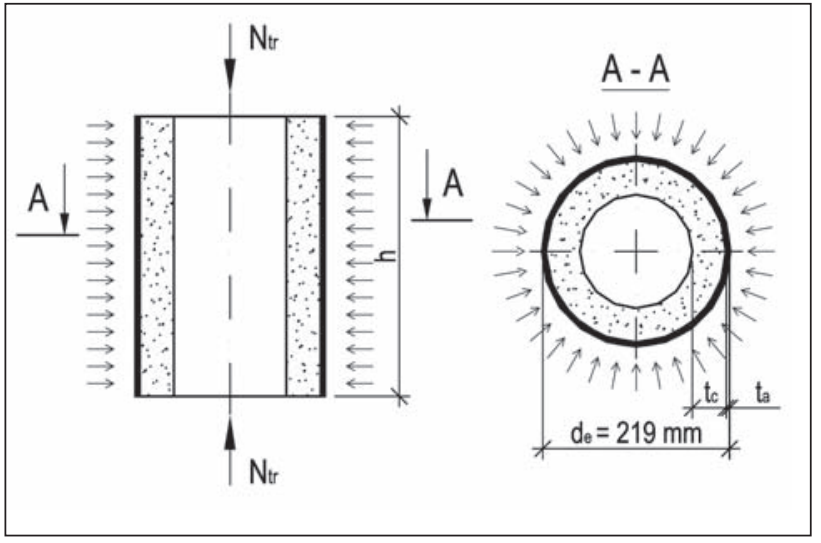

Fig 2. Principal scheme of HC-FST specimen

\subsection{Preheating phase}

For the preheating phase it was foreseen to subject the specimens to axial load and at the same time to heat them. The heating lasted $45 \mathrm{~min}$ for three of HC-FST specimens and $30 \mathrm{~min}$ for one of them. During the breaking stage it was foreseen to apply an axial load on the preheated specimens cooled up to normal $\left(20^{\circ} \mathrm{C}\right)$ temperature and increase load until their fail.

The test equipment was prepared for testing as it was possible in pursuance of the requirements given in [13]. The fixing scheme applied during the preheating stage of the post-fire resistance test allowed to heat the middle part of the HC-FST specimens. The specimens were put into the electric furnace in the vertical position. In order to avoid additional heat losses through non-insulated points of the specimen and obtaining a more uniform distribution of temperature along the structure, the specimen ends protruding from the heating chamber of the furnace (both at the top and at the bottom) were covered with a $50 \mathrm{~mm}$ thick mineral wool mat. At one end of the specimens, notches were made, which formed openings with a cross-section area $0,25 \mathrm{~cm}^{2}$. The function of the openings was to let escape water steam that formed in the inner cavity of the specimen and in the concrete of the core during heating. The scheme of the specimens installation is given in Fig 3 .

The temperature in the furnace was measured by stationary platinum-rhodium thermocouples and using a port- 


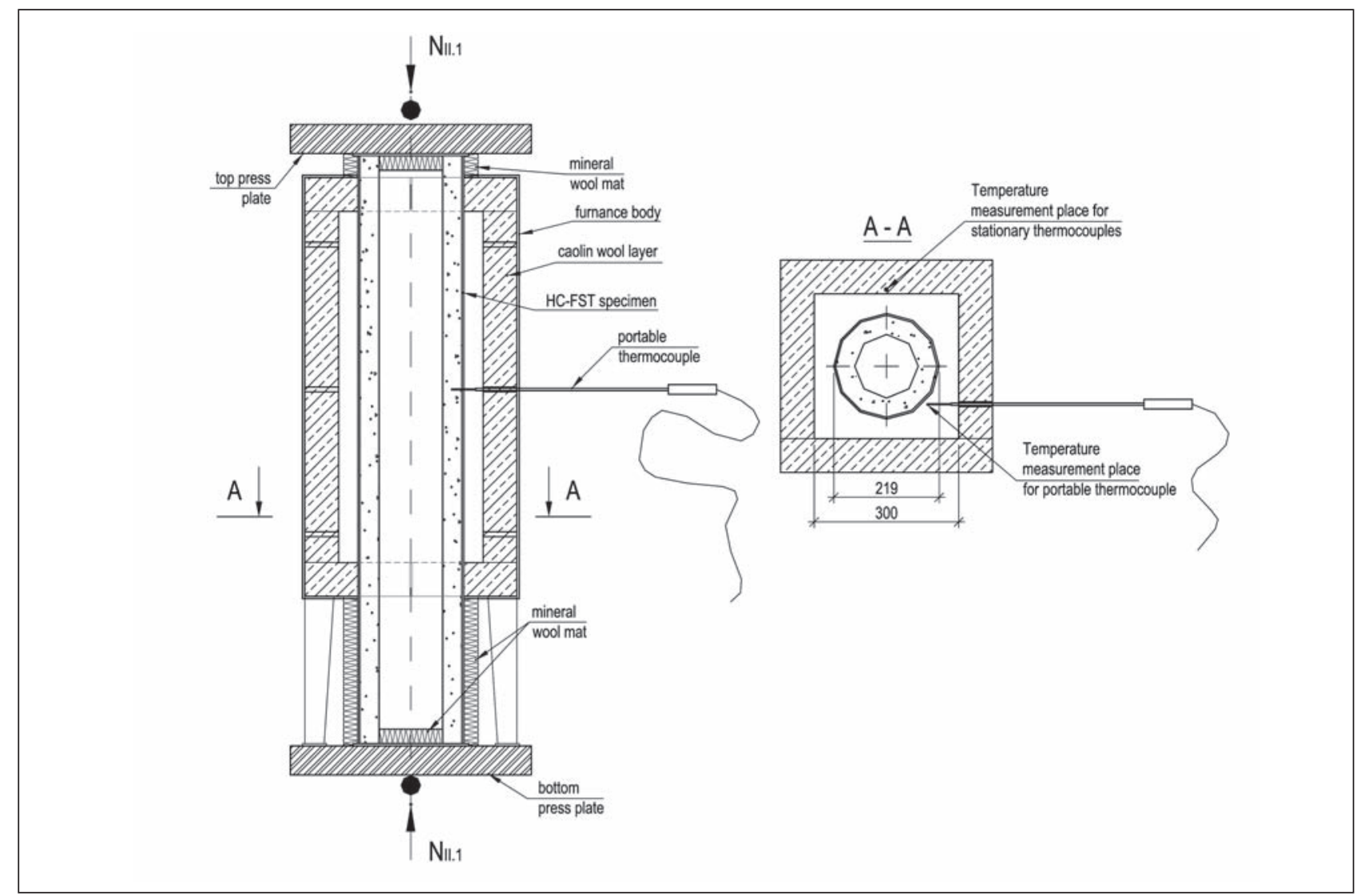

Fig 3. The installation scheme of the specimens for preheating stage

able furnace thermocouple connected to universal data acquisition system ALMEMO 5590-1. Three stationary furnace thermocouples were installed in the heat-insulating layer of kaolin wool in one of the walls of the chamber (at the upper, middle and lower zones of the chamber). The measuring accuracy of the stationary furnace thermocouples was $5{ }^{\circ} \mathrm{C}$ within the measuring range over $300^{\circ} \mathrm{C}$. The measuring accuracy of the portable thermocouple was 0,1 ${ }^{\circ} \mathrm{C}$ within the measuring range from 0 to $1200^{\circ} \mathrm{C}$. The trial temperature regime of the furnace was maintained by a 3channel programmable temperature controller "PROTERM100 ". The temperature controller function is to maintain the trial temperature regime uniform within all the levels of the furnace (lower, middle and upper). During the tests the temperature was maintained as close as possible to the standard fire curve [8]. The maximum temperature in the heating chamber of the furnace reached during the test was as high as $990^{\circ} \mathrm{C}$. Throughout the heating period, the temperature was periodically measured by stationary and portable furnace thermocouples, and the behaviour of the specimens was monitored. The curves of the temperature regime applied during the preheating stage are given in Fig 4.

The curves with code names of the specimens were traced on the basis of temperature measuring data in the heating chamber of the furnace in its hottest point or its vicinity during testing the corresponding specimen. The curves given in the diagram show that after approx $7 \mathrm{~min}$ the temperature in the furnace was slightly higher than the temperature according to the standard fire curve. The speci-

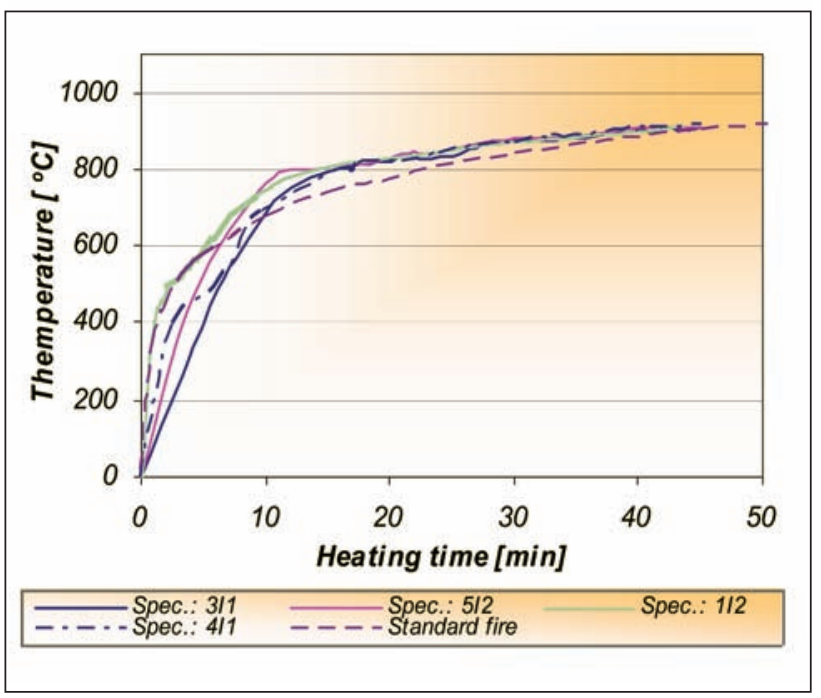

Fig 4. Furnace heating regime during the $1^{\text {st }}$ stage or the Type II test

mens that had been subjected to heating for 45 min were removed from the furnace and allowed to cool for 48 hours.

\subsection{Testing for estimating the load bearing capacity of the specimens}

For strain measuring during the load bearing capacity estimation tests, 8 PKB-type, $50 \mathrm{~mm}$ basis length straingauge transducers each were attached to the outer surface 


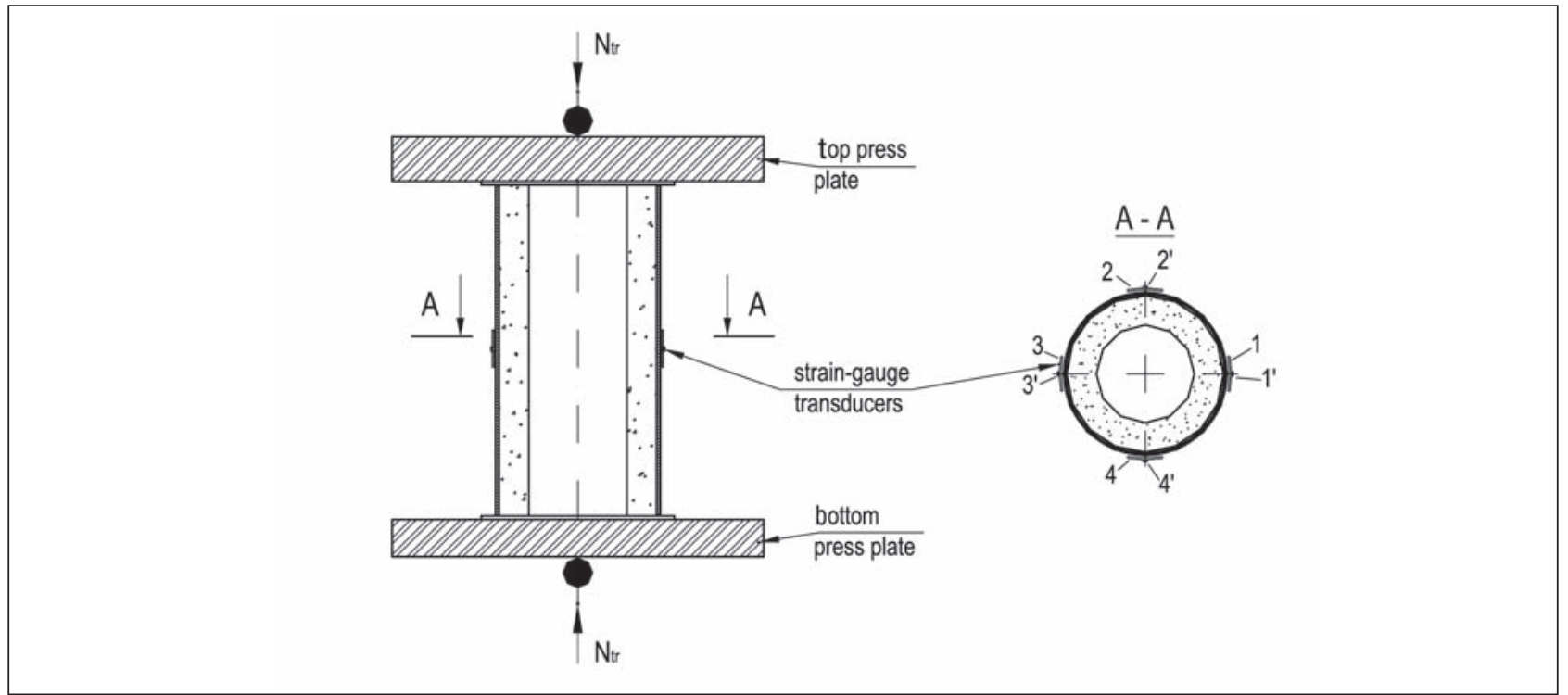

Fig 5. The specimen fixing scheme for compression test

of the $\mathrm{HC}$ and HC-FST specimens in the middle part of the height. 4 transducers each were attached to the specimens in the vertical direction for measuring the longitudinal strains, and 4 transducers each - in the horizontal direction for measuring the transversal strains. The transducers were connected to the universal data acquisition system ALMEMO 5590-2. For measuring the horizontal displacements of the middle part of the HC-FST specimens, the electronic displacement indicators were used. They were fixed independently of the specimen and the press and also connected to the universal data acquisition system ALMEMO 5590-2. The specimen fixing scheme is given in Fig 5. The longitudinal load on the HC-FST and HC specimens was created in the press with its hydraulic jack of 500 tonnes capacity. In respect of every specimen, the concentricity of the load was checked before applying the breaking load to the specimen. The specimens centring was effected by applying a load equal to up to $30 \%$ of the expected failure capacity and by comparing the readings of the strain-gauge transducers. In case of large differences in the readings of strain-gauge transducers attached at the opposite sides of the element, the specimen supporting point was adjusted accordingly. After centring the specimen, the load was increased, and the measuring was carried out from the beginning (at the load value of $0-5 \mathrm{kN}$ ). The average speed of loading was $34 \mathrm{kN} / \mathrm{min}$. The load was increased gradually in $30 \mathrm{kN}$ stages, whereas the readings of the straingauge transducers and displacement measuring devices were recorded at every stage of the load. Under the conditions of a load next to the strength limit of the specimen, the readings of the strain-gauge transducers and the shear measuring devices were recorded every $5-10 \mathrm{kN}$. All the specimens were subjected to testing until their failure.

\section{Experimental results and specimens behaviour}

The failure mode of both short and long HC-FST specimens is quite similar. The specimens without preheating lost their load-bearing capacity because local buckling of the thin-walled steel shell and the hollow concrete core at the ends of the specimen at one of the press plates. All the specimens that were after preheating buckled locally at the points, which had been mostly heated, or in their vicinity. As the failure criterion for the test under ambient conditions was taken, the load bearing capacity at the moment when an irreversible decrease of load carrying capacity in the specimens begins.

The measuring of the horizontal displacements of the long HC-FST specimens (both types - after the preheating and without it) in their middle height fixed very small displacements even just before specimens failing. Measured displacements hardly could be related to the beginning of the overall buckling of the specimen. The observed failure mode of the preheated specimens indirectly endorses the attitude of the [9] for a possibility to decrease substantially the effective length of C-FST columns behaving in fire and after it in comparison with those behaving under normal conditions.

The values of the longitudinal and transversal strains measured at the surface of the steel shell of the HC-FTS specimens in relation to $N_{t r} / N_{u}$ are given in Fig 6 and Fig 7. The main test parameters are given in Table 3 . The view of the specimens tested after preheating is given in Fig 8.

During the $\mathrm{HC}$ specimens testing the recorded mean values of ultimate normal stresses $-\sigma_{u m}=45,44 \mathrm{MPa}$. The mean of ultimate normal stresses have been calculated from the equation: $\sigma_{c r}=N_{c r} / A_{c}$, where: $N_{c r}$-critical experimental load applied to the specimen; $A_{c}$ - the cross-section area of the hollow concrete core of the specimen. According to $[14,15]$, the ring strength of the concrete can be equated with a specific compressive prism strength of concrete $f^{\prime}{ }_{c, m}$. The mean value of the trial steel yield strength was $f_{y, m}^{c, m}=318,3 \mathrm{MPa}$, whereas the mean value of the steel ultimate strength was $f_{u, m}=358,3 \mathrm{MPa}$. 


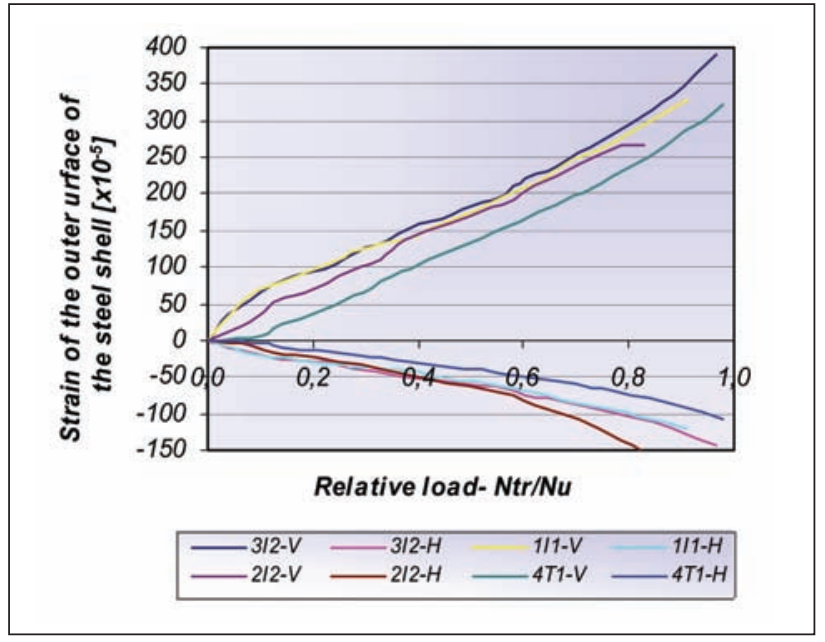

Fig 6. Longitudinal and transversal strains of the steel shell in relation to the relative load $N_{t r} / N_{u}$ of the HC-FST specimens without preheating

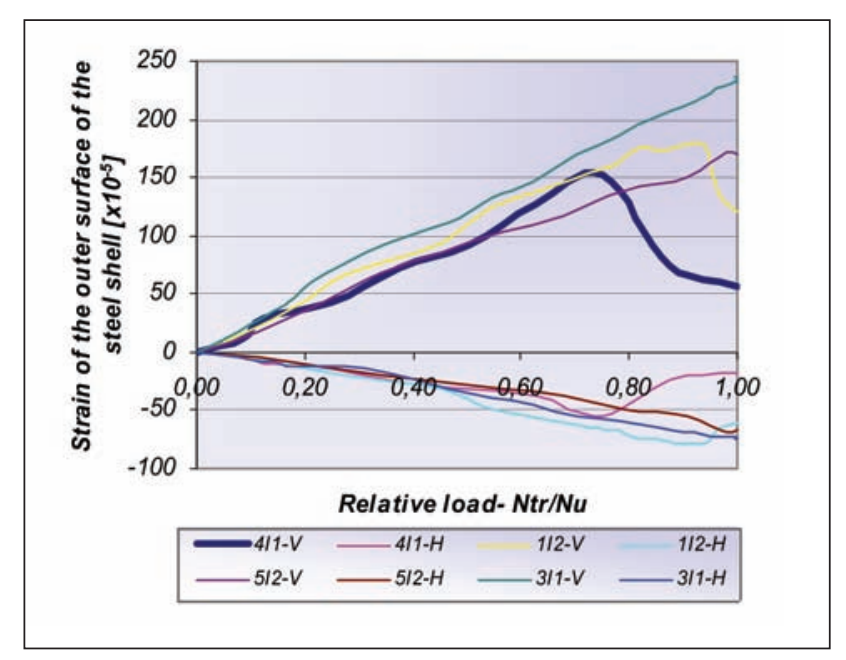

Fig 7. Longitudinal and transversal strains of the steel shell in relation to the relative load $N_{t} / N_{u}$ of the HC-FST specimens after preheating

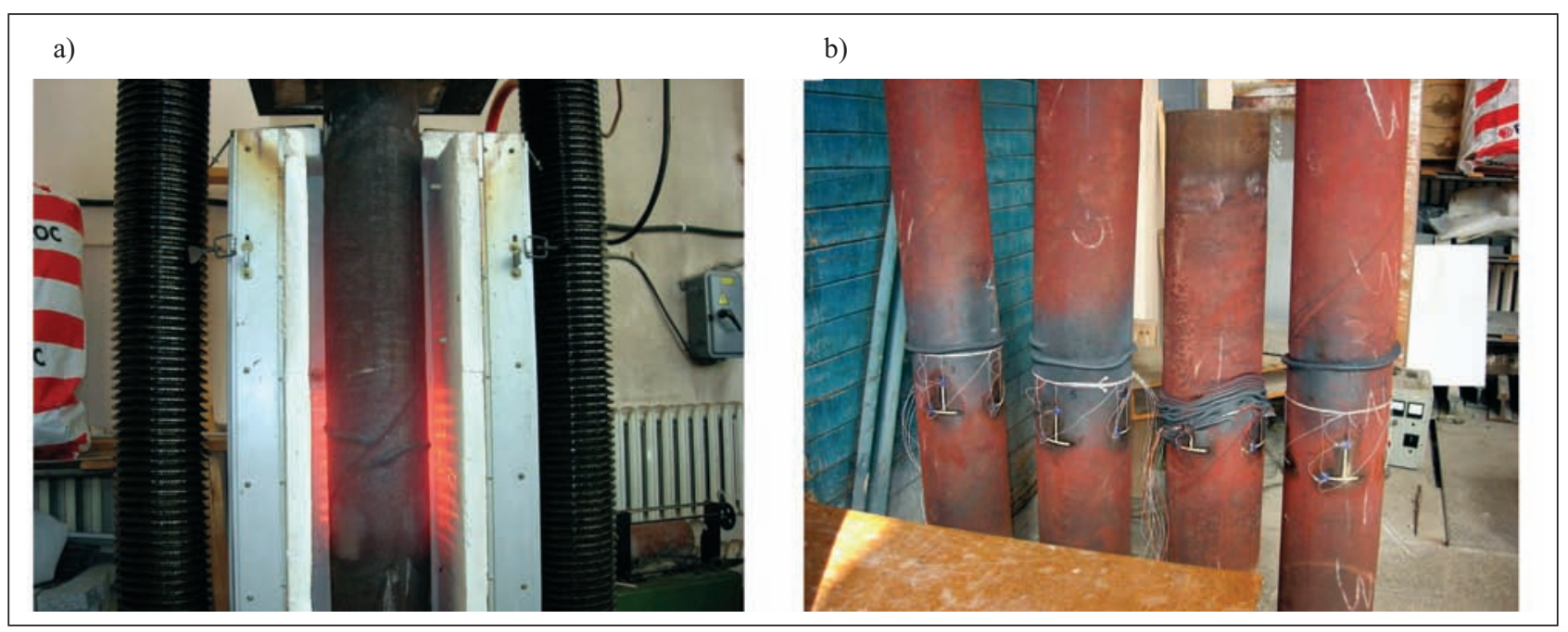

Fig 8. Views on the test specimens tested after the preheating: a) HC-FST specimen just after preheating; b) HC-FST specimens after the compression test

\section{The behaviour of the specimens after recording their maximum load-bearing capacity}

The fact that the specimens did not buckle like column element, but failed locally in the cross-section of the element most affected by heat and were still able to keep some load, prompted us to study the residual load-bearing capacity of the column previously heated during $45 \mathrm{~min}$ and after recording their maximum load-bearing capacity. For this purpose, one Type II test specimen (1I2 - in Table 3) was subjected to further axial compression after the maximum load $(330 \mathrm{kN})$ was already recorded. The element, with the initial geometrical length of $1997 \mathrm{~mm}$, was further tested until its length decreased to $1700 \mathrm{~mm}$. The minimal resisting force of the specimen, recorded during this particular test was $85 \mathrm{kN}$, i.e. $25,8 \%$ of the maximum experimentally determined it's load-bearing capacity. After the minimal load value was reached, axial load-bearing force during further testing raised up to $175 \mathrm{kN}$. At the end of the test (when that element had lost $300 \mathrm{~mm}$ of its initial geometrical length) the load-bearing force of the HC-FST specimen made up $105 \mathrm{kN}$.

Observation of the specimen behaviour under axial compression after preheating under partial loading and after recording it maximum load-bearing capacity showed the further possibility to resist some load portion. That may be important expecting a particular service of HC-FST columns before their final failure.

\section{Estimation of the study results}

The residual (post-fire) compressive resistance of the specimen determined during the Type II tests (after a $45 \mathrm{~min}$ preheating regime) on average makes up $41 \%$ of the trial load-bearing capacity of specimens tested under normal conditions, and approx $134 \%$ of the mean load value, which was applied during heating. According to obtained trial value 
Table 3. Main parameters of the tests

\begin{tabular}{|c|c|c|c|c|c|c|c|c|c|}
\hline No & $\begin{array}{c}\text { Type of the } \\
\text { specimen } \\
\text { cross-section }\end{array}$ & $\begin{array}{c}\text { Code of } \\
\text { the } \\
\text { specimen }\end{array}$ & $h[\mathrm{~mm}]$ & $t_{a}[\mathrm{~mm}]$ & $t_{c, \text { mean }}[\mathrm{mm}]$ & $\begin{array}{c}\text { Type of the } \\
\text { test }\end{array}$ & $N_{u e}[\mathrm{kN}]$ & $\left.t_{\max }{ }^{\circ} \mathrm{C}\right]$ & $T[\mathrm{~min}]$ \\
\hline 1 & HC-FST & $1 \mathrm{II}$ & 2004,0 & 1,65 & 20,10 & $\mathrm{I}$ & 625 & - & - \\
\hline 2 & HC-FST & $2 \mathrm{I} 2$ & 1992,0 & 1,60 & 28,90 & $\mathrm{I}$ & 690 & - & - \\
\hline 3 & HC-FST & $3 \mathrm{I} 2$ & 2000,0 & 1,60 & 31,90 & $\mathrm{I}$ & 745 & - & - \\
\hline 4 & HC-FST & $5 \mathrm{I} 1$ & 1999,0 & 1,63 & 24,875 & $\mathrm{I}$ & 725 & - & - \\
\hline 5 & HC-FST & $0 \mathrm{~T} 1$ & 295,0 & 1,60 & 15,65 & $\mathrm{I}$ & 605 & - & - \\
\hline 6 & HC-FST & $1 \mathrm{~T} 1$ & 300,0 & 1,65 & 23,60 & $\mathrm{I}$ & 980 & - & - \\
\hline 7 & HC-FST & $2 \mathrm{~T} 1$ & 298,0 & 1,60 & 15,90 & $\mathrm{I}$ & 860 & - & - \\
\hline 8 & HC-FST & $2 \mathrm{~T} 2$ & 298,5 & 1,60 & 25,50 & $\mathrm{I}$ & 940 & - & - \\
\hline 9 & HC-FST & $3 \mathrm{~T} 1$ & 298,0 & 1,60 & 16,15 & $\mathrm{I}$ & 755 & - & - \\
\hline 10 & HC-FST & $3 \mathrm{~T} 2$ & 298,0 & 1,60 & 16,55 & $\mathrm{I}$ & 550 & - & - \\
\hline 11 & HC-FST & $4 \mathrm{~T} 1$ & 298,0 & 1,63 & 19,025 & $\mathrm{I}$ & 860 & - & - \\
\hline 12 & HC-FST & $5 \mathrm{~T} 1$ & 296,0 & 1,63 & 24,375 & $\mathrm{I}$ & 810 & - & - \\
\hline 13 & HC-FST & $1 \mathrm{I} 2$ & 1997,0 & 1,65 & 28,60 & II.1 & $(180) 330$ & 960 & 45,0 \\
\hline 14 & HC-FST & $3 \mathrm{II} 1$ & 1999,0 & 1,60 & 32,40 & II.1 & $(180) 385$ & 918 & 30,0 \\
\hline 15 & HC-FST & $4 \mathrm{II}$ & 1998,0 & 1,63 & 25,125 & II.2 & $(120) 270$ & 964 & 45,0 \\
\hline 16 & HC-FST & $5 \mathrm{I} 2$ & 1998,0 & 1,63 & 23,125 & II.1 & $(180) 265$ & 990 & 45,0 \\
\hline
\end{tabular}

Notes:

1. The meanings of the markings in the Table columns: $h$ - element length; $t_{a}$-steel shell thickness; $t_{c, \text { mean }}-$ mean thickness of the concrete ring of the element; $N_{\text {ue }}$ - the trial load-bearing capacity for axially loaded specimen (the value in brackets means the value of the axial load during the preheating of the specimen); $t_{\max }$ - the maximum temperature of the furnace reached during the Type 1 test $1^{\text {st }}$ stage, $T$ - the duration of preheating of the specimen during the Type 1 test $1^{\text {st }}$ stage.

2. Test type marking and test type description accordingly are:

- „I“- determining the compressive strength of the whether HC-FST, or HC specimen axially loaded under normal ambient conditions;

- „II.1“ - determin ing the compressive strength of the HC-FST specimens at ambient conditions following the 45 min heating and loaded with an $180 \mathrm{kN}$ axial load;

- „II.2“ - determin ing the compressive strength of the HC-FST specimens at ambient conditions following the 45 min heating and loaded with an $120 \mathrm{kN}$ axial load;

( $41 \%$ ) of load-bearing capacity of HC-FST columns in postfire conditions and taking into account that according to [8] the design load applied on the structures in analysis of the most civil buildings under fire conditions makes up approx $40 \%$ of the design load under normal $\left(t=20^{\circ} \mathrm{C}\right)$ conditions it can be assumed that the load bearing capacity of the HC-FST columns (with geometrical parameters similar to those of tested columns) is the almost very similar for the preheated as well as for the preheated and then cooled columns (with the duration of heating - $45 \mathrm{~min}$ ).

Calculation of temperature distribution in the section of the column under testing presented in [7] showed the temperature magnitude of concrete core $10-15 \%$ less than temperature inside the furnace chamber during heating. It is seen that the calculated value of the temperature distribution (neglecting the water existence within the concrete core) is not well adequate with the experimental data as the water steam was clear observed for $30 \mathrm{~min}$ from the beginning of the heating. The calculated by FEM modelling temperature distribution in the cross-section of HC-FST column after $45 \mathrm{~min}$ from the beginning of the standard [8] fire is shown in Fig 1.
In [6] it is given that the design residual strength of concrete (after its preheating to the $500{ }^{\circ} \mathrm{C}$ and higher temperatures) conservatively can be neglected (although it may amount the $30 \%$ of initial strength) but the residual (cooled after preheating) strength of the steel (with the characteristic values of strength in tension equal to $375 \mathrm{MPa}$ and less) makes up $100 \%$ of its strength under normal conditions. Hence, we would be able to assume the post-fire resistance of HC-FST column (after its preheating until steel shell and concrete core had reached $500{ }^{\circ} \mathrm{C}$ and higher temperature) consisting of only the compressive resistance of the steel shell.

Compressive resistance of the CHS columns (with the mean geometrical and mechanical properties of steel shell of the tested HC-FST specimens) under the ambient conditions was determined from calculations according to [16] and [17] and makes up $-302,6 \mathrm{kN}$. This value obtained by calculation is just a little lower than mean trial value of HC-FST specimens' post-fire resistance $(312,5 \mathrm{kN})$.

The compressive resistance of the HC-FST column with geometrical parameters of the tested specimens (from Table 1) in ambient temperatures calculated according to 
[18] makes up $635 \mathrm{kN}$ and is quite close to the experimental mean value $696 \mathrm{kN}$.

Also, the analysis of the compressive resistance of the same CHS column under fire conditions was made. Compressive resistance of the CHS column under fire conditions after $45 \mathrm{~min}$ of heating was obtained as the result of calculation according to [19] and makes up only $18.02 \mathrm{kN}$. It is 10 times less than the axial load $(180 \mathrm{kN})$ applied on the HC-FST specimens during the preheating stage of postfire resistance tests.

By the analysis of experimental results and calculation results it can be stated that the greater portion of the load applied to the HC-FST column is taken by concrete core in fire situation (or during the preheating) and by the steel shell - when preheated HC-FST column is cooled to a normal temperature.

\section{The main conclusions}

1. On the basis of the analysis of tests results, it can be stated, that after the exposing to fire temperatures with duration of $45 \mathrm{~min}$, the residual compressive resistance of the HC-FST columns is not sufficient for further normal use of the structures, but allows expecting a particularly safe use during a small period of time. In the buildings with statically indeterminate frameworks after the fire it is believable redistribution of internal forces between HC-FST columns due to their plastic failure mode and ability to take a relatively great (in comparison with their post-fire resistance) the post-failure load.

2. According to the test data residual (post-fire) compressive resistance of HC-FST specimens makes up about $41 \%$ of the resistance of those elements under ambient conditions. This experimentally obtained utilisation level value of HC-FST columns under post-fire conditions is very close to the usually taken level (40\%) of design load for fire analysis of structures.

3. Observation of the behaviour of the HC-FST specimens under axial compression and previously affected by fire temperatures, allows us to expect not a sudden failure mode via the overall buckling of HC-FST columns but the failure mode that could be described as local buckling of the thin-walled steel shell and local failure of the hollow concrete core.

4. From the water steam emission observation it can be stated that a temperature distribution in the section of columns during testing is substantially influenced by the availability of free and chemically combined water in the concrete core of HC-FST element. Water inside the concrete should be always estimated in analysis of temperature distribution through the cross-section of the HC-FST column under heating.

5. The concrete core takes the greater part of the axial load applied to the CH-FST column during the fire, but is not well resisting in post-fire situation. The steel shell takes the greater part of the axial load acting on the preheated and then cooled CH-FST column but is not well-resisting the normal stresses in fire.

\section{References}

1. KVEDARAS, A. K. and ŠAPALAS, A. Effective steel and concrete structures and possibilities of their application. Technological and Economic Development of Economy, 2004, Vol X, No 2, p. 77-81.

2. KRASNOVSKY, B. M. The estimating of the temperature according to the cooling period. Technological and Economic Development of Economy, 2004, Vol X, No 4, p. 150-160.

3. COLINA, H.; MOREAU, G. and CINTRA, D. Experimental Study of Transient Thermal Creep and Other Phenomena of Concrete at High Temperature. Journal of Civil Engineering and Management, 2004, Vol X, No 4, p, 255-260.

4. BEDNAREK, Z. The influence of the temperature increase on the steel strength properties used for the appraisal of the fire safety of the reinforced concrete structures. Dissertation for Habilitation. Technical sciences, Civil Engineering (J7). Vilnius: Technika, 1996 (in Russian).

5. BEDNAREK, Z.; and KAMOCKA, R. Analysis of thermal strain of structural steels in variable thermal field. Journal of Civil Engineering and Management, 2004, Vol X, Suppl 1, p. 19-22.

6. MOSALKOV, I. L.; PLIUSINA, G. F. and FROLOV, A. J. Fire resistance of building structures (Огнестойкость строительных конструкций). Moscow: Spectechnika, 2001, 481 p. (in Russian).

7. BLAŽEVIČIUS, Ž. and ŠAUČIUVĖNAS, G. The course of an experimental research on the fire resistance of HC-FST columns and the results of their calculation In Proc of the scientific conference "Building structures - Dvelopment of Building Structures During Integration to the Space of Eurocodes". Vilnius, Lithuania, Mar. 2006 (in press. In Lithuanian).

8. EN 1991-1-2:2002. Eurocode 1 - Actions on structures. Part 1-2: General actions. Actions on structures exposed to fire. European Committee for Standardization, Brussels, Jan 2002. $59 \mathrm{p}$.

9. LST EN 1994-1-2:2006. Eurocode 4 - Design of composite steel and concrete structures - Part 1-2: General rules - Structural fire design. (Eurokodas 4. Kompleksiniu plieniniu ir betoninių konstrukciju projektavimas. 1-2 dalis. Bendrosios taisyklès. Konstrukciju gaisrinès saugos projektavimas). Vilnius: LSD, 2006. 109 p.

10. HAN, L.-H. and HUO, J.-S. Concrete-Filled Hollow Structural Steel Columns After Exposure to ISO-834 Fire Standard. Journal of Structural Engineering, 2003, Vol 129, No 1, p. 68-78.

11. KVEDARAS, A. K. and BLAŽEVIČIUS, Ž. Experimental evaluation of compression resistance of HC-FST columns after fire. In Proc of the $4^{\text {th }}$ International Workshop Structures in Fire - SIF'06 (Held Aveiro, Portugal, 10-12 May, 2006), Edit. By P. V. Real; J.-M. Francen; N. Lopez.

12. LST EN 10002-1:2003 Metallic materials. Tensile testing. Part 1: Method of test at ambient temperature (Metalai. Tempimo bandymas. 1 dalis. Bandymo metodas aplinkos temperatūroje). Vilnius: LSD, 2003. 56 p.

13. LST EN 1363-1:2000. Fire resistance tests. Part 1: General requirements (Atsparumo ugniai bandymai. 1 dalis. Bendrieji reikalavimai). Vilnius: LSD, 2000. 49 p.

14. VADLŪGA, R. and KUDZYS, A. On the compressive strength of the centrifuged concrete. Transactions of KPI. Researches on the Reinforced Concrete Structures, Vol 1. Vilnius: Mintis, 1966, p. 111-116 (in Russian).

15. KUDZYS, A. Reinforced concrete structures of annular crosssection (Железобетонные конструкции кольцевого 
сечения). Vilnius: Mintis, 1975 (in Russian).

16. STR 2.05.08:2005. Desing of steel structures. General rules (Plieninių konstrukcijų projektavimas. Pagrindinès nuostatos). Vilnius: Rekona, 2005. 95 p. (in Lithuanian).

17. EN 1993-1-1. Eurocode 3: Design of steel structures - Part 11: General rules and rules of buildings. European Committee for Standardization, Brussels, May 2005. 91 p.
18. LST EN 1994-1-1:2005. Eurocode 4 - Design of composite steel and concrete structures - Part 1-1: General rules and rules for buildings (Eurokodas 4. Kompleksiniu plieniniu ir betoniniu konstrukciju projektavimas. 1-1 dalis. Bendrosios ir pastatu taisyklès). Vilnius: LSD, Apr. 2005. 118 p.

19. EN 1993-1-2. Eurocode 3: Design of steel structures - Part 12: General rules - Structural fire design. European Committee for Standardization, Brussels, April. 2005. 78 p.

\section{VAMZDINIU巳 PLIENO KOLONU SU BETONO ŠERDIMI NAUDOJIMO GALIMYBĖS, ATSIŽVELGIANT I} LIEKAMOJO ATSPARUMO KAITRAI BANDYMU REZULTATUS

\section{Ž. Blaževičius}

\section{Santrauka}

Šio tiriamojo darbo tikslas - ivertinti plieno kolonu su betono šerdimi eksploatacijos po gaisro galimybes. Pateikiamos plieno ir betono, paveiktų kaitra, savybès, taip pat požymiai, pagal kuriuos galima spręsti, kokią temperatūrą buvo pasiekusi konstrukcija gaisro metu. Straipsnyje aprašytas HC-FST (vamzdiniu plieno kolonų su tuščiavidure betono šerdimi) eksperimentinis tyrimas. Eksperimentiškai buvo ištirti 16 centriškai apkrautų HC-FST elementu, pateikti tyrimo rezultatai. Liekamojo atsparumo po eksploatacijos kaitros sąlygomis eksperimentinès reikšmès nustatytos 4-ioms centriškai gniuždomoms kolonoms. Bandymo parametrams palyginti buvo išbandyti 4 trumpi HC-FST elementai, 8 HC-FST kolonos ir 4 trumpi betoniniai žiedinio skerspjūvio elementai. Vienas iš pagrindinių straipsnyje aprašyto tyrimo tikslų - paruošti eksperimentinius duomenis, reikalingus analizei atlikti ir priklausomybèms tarp bandymo parametru, labiausiai veikiančių HC-FST liekamaji atsparumą kaitrai, išvesti.

Reikšminiai žodžiai: mechaninès savybès, eksperimentinis tyrimas, vamzdinès plieno kolonos su betono šerdimi, liekamasis atsparumas ugniai, laikomoji galia, ašinė apkrova.

Žygimantas BLAŽEVIČIUS. MSc (CE), PhD student from 2002 at the Dept of Steel and Timber Structures of Vilnius Gediminas Thechnical University. Field of research: composite steel-concrete structures. 